\title{
The Driving Forces of Business - Innovation, Success and Human Resources
}

\author{
Renáta MACHOVÁ ${ }^{1}$, Andrea BENCSIK ${ }^{2}$, Monika ŠIMONOVÁ ${ }^{1}$ \\ ${ }^{1}$ J. Selye University, Komárno, Slovak Republic \\ \{machovareujs, simonovaa\}@ujs.sk \\ ${ }^{2}$ Széchényi István University, Győr, Hungary \\ bencsikesze.hu
}

\begin{abstract}
To survive in an increasingly competitive business environment of the globalized world the primary task of businesses is to ensure and manage human resources to achieve economic growth, gain market share and remain successful. The success of business is made up of several factors. The most important factors are: innovation, motivation and the highest emphasis is put on human resources. Innovation, as a catalyst of progress is playing an increasingly important role to ensure competitiveness and maintain sustainable development. The main objective of the paper is to introduce and examine success, innovation and human resources on theoretical level as well as utilization of this knowledge in international practice, as they are applied in Central and Eastern European subsidiaries.
\end{abstract}

Keywords: Innovation, Human Resources, Management, Motivation.

\section{Introduction}

Shaping future processes has always been a desire of mankind. The primary task of businesses in increasingly competitive business environment is to ensure resources to gain economic growth, increase market share and achieve success. Different factors can determine the success of the business. Innovation, motivation and human resources play the most important role to maintain competitiveness. Innovation is a key to sustain development and considered to be an engine of progress [9].

The secret of success is explained in different ways. The basic elements of success are: learning, setting objectives, positive thinking, enthusiasm, strategy, relationships, reliability and flexibility. „Innovation” comes from the Latin word of ,innovatus”, which refers to something new, but also means ,to renew or change" something. Innovation in society is a process, when new ideas are born and transformed into values. There is a gap between the concept of innovation and the organization's ability to create value. Nowadays, innovation plays an important role in providing prosperity, maintaining competitiveness and sustaining development [2, 6]. According to Schumpeter, innovation leads to development of new products and processes, requires the use of new resources, implementation of new organizational structures 
and entering new markets. Freeman differentiates four categories of innovation process: incremental innovations, radical innovations, production process changes and paradigm shifts. Nowadays successful enterprises appreciate not only knowledge and experience of their employees but also their willingness to cope with all difficult tasks [6]. The Oslo Manual is an international source of guidelines for the collection of data on innovation. The Frascati Manual is an essential tool which contains data collection guidelines and classifications for compiling R\&D statistics. The Patent Statistics Manual provides guiding principles for the use of patent data. The Canberra Manual is intended to provide guidelines for the measurement of Human Resources devoted to Science and Technology and the analysis of such data. The OECD has made a great effort to clarify and harmonize the concepts related to innovation and the methods measuring innovation. Innovation incubators play an important role in regional levels of innovations [5, 12]. A new concept of responsible innovation was introduced. The social aspect of responsible innovation is complex. The most important feature of responsible innovation is the improved quality of life as a welfare indicator. The development of technology and increasing innovation can result in job losses, therefore other undesirable social consequences may appear [3].

\section{Innovation and Human Resources}

Nowadays money and assets can be quickly mobilized and rearranged, but it is more difficult to do it with the appropriate workforce. The accelerated processes have made the individual and human knowledge the most important indicator. The human resource will be the most important strategic resource for the organizations in the future. Societies and organizations can experience downturns and losses, but it is easier to survive if employees remain. Similar views are followed by managers. They think that dealing with people is a sensitive and responsible task.

We use the term of human resources for entire population of a country or nation. In the following chapters we will use the concept for individuals working for an organization. The company management should be careful with decision making and implementation of their decisions concerning the company employees [16]. Human resource management is primarily concerned with the management of people within an organization, recruitment of staff, training and development of employees in order to achieve organizational goals. It is essential to mutually consider the needs and objectives of employees and the organization, train and shape the attitude of the staff and develop mutual commitment of the partners. Several approaches deal with the problems of weightless economy and intellectual capital. According to different opinions, the new economy will not follow the rules of classical economics. Others argue that the economic law is outdated and extremes prevail, while some share an opinion that knowledge and knowledge capital are not considered to be part of economic processes. There is no doubt that knowledge has become a critical resource and competitive factor in the economy. Many industrial activities find knowledge capital more important than the intangible capital. 


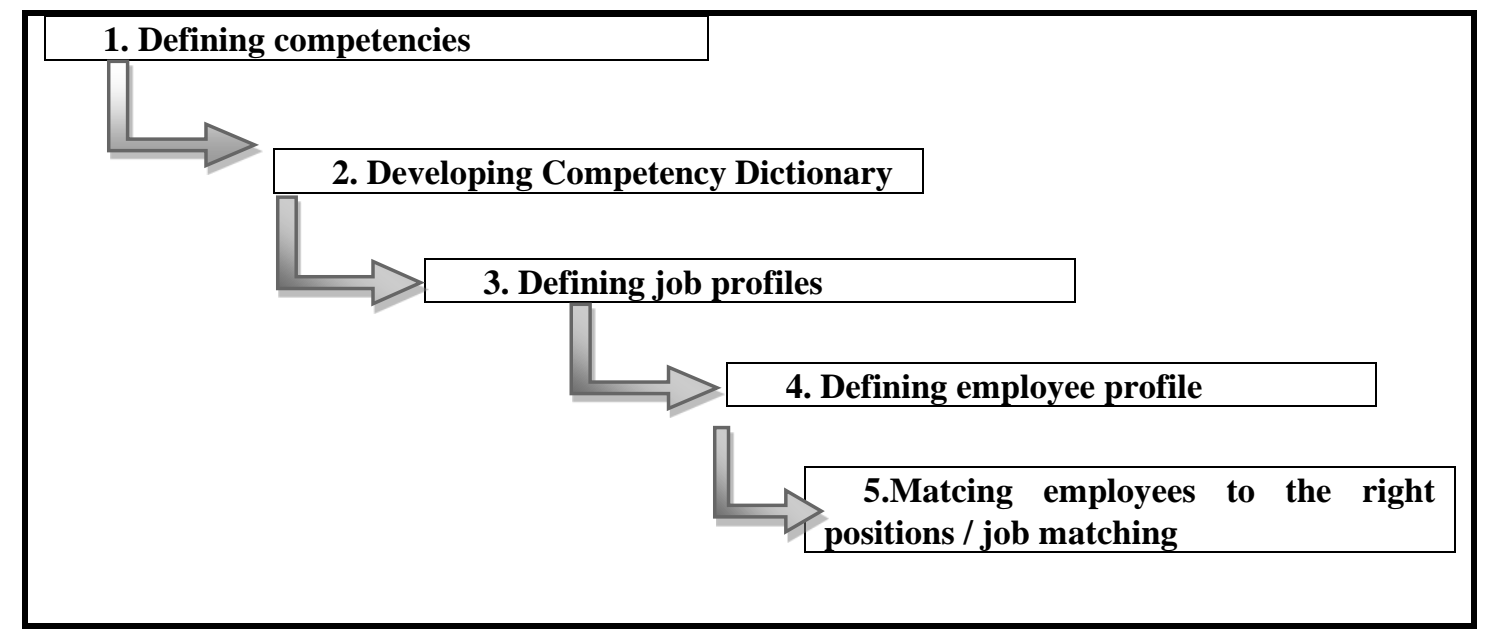

Fig. 1.. The Competency Model and its Implementation, [9].

There is a debate between professionals about the relationship between the economic development and population growth. Optimists argue that competition is mainly determined by demographic indicators, while others argue that rapid population growth will have negative impact on the development of organizations and businesses.

Organizations going through change experience an increase or decrease of employees. If companies are expanding, they will increase the number of employees, while going through tougher periods will result in reduction of staff. The change of employee number is a complex problem for HR specialists, which can be a sign of implementation of new strategy, organizational development or change.

The intellectual capital should be utilized to build strength, abilities and competencies to maintain relevance and competitiveness. The unpredictability of the work environment, work possibilities and the labour migration should be considered. HR specialists should help companies to gain a competitive edge and should spend more time on developing company strategy, technologies and getting to know their competitors and customer needs. Good strategies are needed to develop new methods and information should be gathered to forecast the change. It is important to apply modern technologies rationally and take into consideration the well-performing and weaker performing employees. It is important to shape the future, achieve high standards and reward excellent performance. The focus is on the individual, but more emphasis is placed on the responsibility of company's achievements. The future generation of HR specialists will be a hybrid [13, 14]. 


\section{$3 \quad$ Research Objectives and Methodology}

The main objective of this research is to introduce how theory is implemented in practice in the field of innovation, HR, motivation and success. We would like to focus on answers to the following hypothesis:

Innovation, as the main engine of the economy is understood, experienced and perceived positively by employees. Innovation will help employees and make their work easier. They support innovation and accept that there is no progress and development without it. Development secures the stability of jobs. The company values innovative efforts of its employees.

The company was founded in 1874 and headquartered in Lucerne, Switzerland. It has developed a lot since its establishment. Plants and production lines of the company can be found in more than 100 countries. In Europe, it is the biggest and worldwide the second biggest company in elevator production and distribution. The company is a world leader in production of escalators and moving walkways. The number of employees is over 56000 . The company has been operating on the Slovak market since 1995 decided on further expansion.

The main objective of our primary research is to find out and introduce how employees of the company are motivated and what role innovative solutions play in the company. We applied qualitative and quantitative methods in our research. The hypothesis we set is based on quantitative research results, so we do not deal with the results of qualitative research conducted. In selected subsidiaries we delivered questionnaires to 1500 e-mail addresses via internal communication system. 380 questionnaires were returned, but only 345 were evaluable which means $23 \%$ success rate. Deductive and inductive approach was applied to process theoretical information and research data.

A frequently asked question is why a person is different from other? It can be explained by instinctive behaviour and childhood experience. Based on these facts, people fall into different stereotypes; however the human personality is complex and diverse [10]. Nowadays companies face not only the problem of smoking and alcohol consumption of employees, but drug addiction as well. The control of this situation means extra burden for the company. According to Herzberg, the existence of hygiene factors reduces or eliminates employee dissatisfaction. It can increase the employee commitment and they are less likely to leave their job, but will not result in increased motivation and performance [4] only few companies pay attention to decrease workplace stress. Stressful work environment increases the number of workplace accidents by $30 \%$ [17]. $75 \%$ of employees can provide better performance on workplace if they experience positive feedback. 9,9\% of the respondents rejected the possibility of motivation and refused to perform better even if there is any kind of reward for their performance. $15 \%$ of the employees considered it for extra performance. Employees show willingness to make an effort that benefit them and estimate the expected return before choosing the best option [1].

Different motivational tools were used, but we highlighted only those which were the most popular among respondents involved in our research. 
For better transparency all answers received from respondents will be evaluated separately.

- Salary increase: ,very good” option was chosen by $75 \%$, ,good” option by $13 \%$ and „less good” by $4.9 \%$ of the respondents.

- Workplace recognition: „very good” option was chosen by $44.4 \%$, „good” option by $37 \%$ and „less good" option was chosen by $3.7 \%$ of the respondents.

- Job security: „,very good” option was chosen by $50.6 \%$, ,good” option by $28.3 \%$ and „less good" option was chosen by $4.9 \%$ of the respondents.

- Chance of promotion: „,very good” option was chosen by $44.4 \%$, ,good” option by $19.7 \%$ and „less good" option was chosen by $7.4 \%$ of the respondents.

- Working time: ,very good" option was chosen by $38.2 \%$, ,good” option by $28.3 \%$ and „less good" by $3.7 \%$ of the respondents.

- Work environment: "very good” option was chosen by $28.3 \%$, „good” option by $39.5 \%$ and „less good" option was chosen by $3.7 \%$ of the respondents.

- Income level: „very good” option was chosen by $45.6 \%$, „good” option by $17.2 \%$ and „less good" option was chosen by $8.6 \%$ of the respondents.

- Benefits: „,very good” option was chosen by $51.8 \%$, ,good” option by $14.8 \%$ and „less good” option by $9.8 \%$ of the respondents.

Motivating factors received positive evaluation. If we summarize the ratio of positive responses, less positive answers can be considered negligible. The most popular motivating factor is salary increase. Money can lose its motivating power in long run and will be replaced by other tools to maintain motivation. Our respondents marked money as the most motivating factor. Based on Herzberg's two factor theory of motivation both motivators and the hygiene factors are important for respondents.

„Herzberg found that:

- Satisfaction is not the opposite of dissatisfaction, but the absence of satisfaction. Job satisfaction depends on motivators;

- Dissatisfaction with the job is not the opposite of job satisfaction, it is the absence of job dissatisfaction - dissatisfaction depends on the physical and social environment, colleagues and managers [7].

Below we will focus on fringe benefits motivating the employees of the company. 


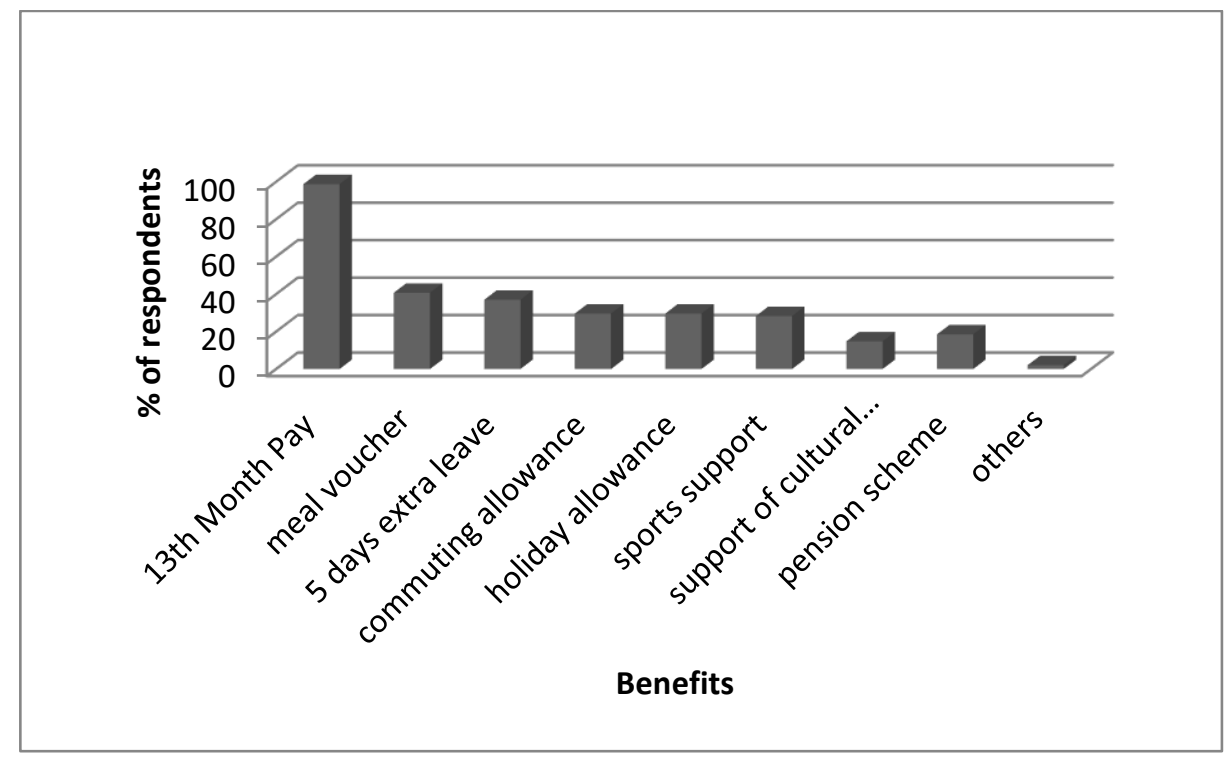

Fig. 2. Fringe benefits

98.7\% of the respondents find 13th Month Pay the most motivating factor, 40.7\% voted for meal voucher, commuting allowance is attractive for $29.6 \%$, holiday allowance was chosen by $29.6 \%$ and sports support by $28.3 \%$ of the respondents. Support of cultural events got $14.8 \%$ of the votes, 5 days extra leave was attractive for $37 \%$ and pension scheme contribution by the company attracted $18.5 \%$ of the respondents. In category „Others” two entries were made.

The results show that financial benefit is still the most important motivating factor among the respondents. Other types of benefits were less attractive for employees. In category "Others" one of the respondents found all the listed types of benefits motivating, while other respondent would welcome a training allowance.

People spend less time working and get more money, therefore enjoy higher security and this trend is irreversible. The benefits are not considered to be as a reward for better performance but something granted for work done. Positive corporate culture contributes to employees' willingness to get involved in the enterprise goals, to strengthen initiative and quality of work, to support their loyalty and responsibility towards the enterprise and to make the communication within the enterprise more effective [8]. The response we received for question 26 clearly shows that innovative solutions make work easier for the employees. There are four possible answers for this question, but only one answer can be accepted. (yes, no, make it easier, make it difficult) 


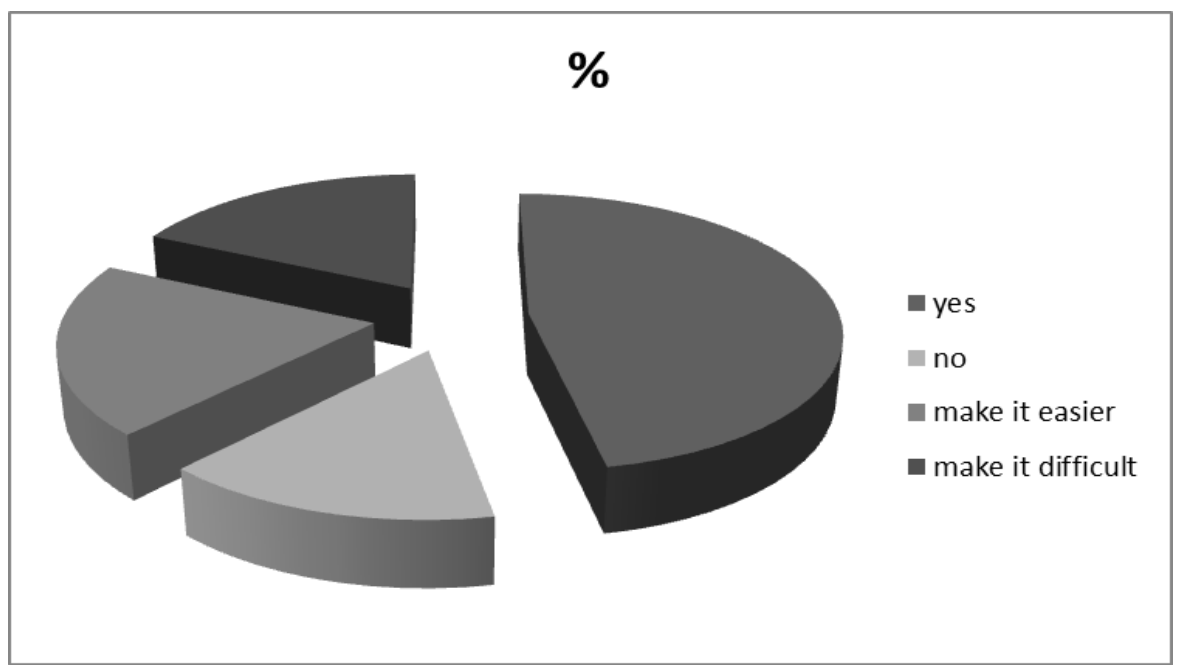

Fig. 3. Do innovative solutions help work?

The research results show the following answers: 16 respondents feel that innovative solutions help their work, while 12 respondents voted for „no” answer. 38 employees from all the respondents answered that innovative solutions make their work easier and 15 think, their work is more difficult.

Summarizing the data available we can declare, that $66.66 \%$ of the employees found innovative solutions helpful. It must also be said, that $33.33 \%$ of the respondents do not find innovative solutions helpful.

To obtain data it was important to work out the questionnaire. Data collected in our questionnaire research helped to support or reject our hypotheses. The studied phenomenon is interpreted in comparison to other variables. We applied statistical analysis to examine the relationship between the responses. Answers to questions are not expressed numerically, but provide quality values which reflect associative relationship.

We applied a contingency table to examine the relationships between the variables. We must consider, whether the chosen method meets the requirements of the analysis, e. g. the expected value in a cell cannot be less than 1 .

The Chi-Square, Cramer and Chuprov's coefficients of associations may have values between 0 and 1 , where 0 indicates full independence and 1 indicates a function-like relationship between the variables.

Hypothesis: Innovation, as the main engine of the economy is perceived and understood positively by employees.

The evaluation of Hypothesis we start with the introduction of results obtained through qualitative research. The research and development is conducted in Switzerland, but innovative ideas are dealt with on local level as well. Financial reward and bonus is provided for innovators, whose ideas can be utilized by the company. 
As the results of our quantitative research show, $66.66 \%$ of employees found innovation important. Finding new opportunities will ensure the continuity of production and the stability of workplaces.

Statistical method will be used to examine the possibility of correlation between the indicators.

$$
\begin{gathered}
\text { Chi-Quadrat } \\
\chi^{2}=\sum_{i=1}^{r} \sum_{j=1}^{c} \frac{\left(f_{i j}-f_{i j}^{*}\right)^{2}}{f_{i j}^{*}}
\end{gathered}
$$

\section{Cramer's contingency coefficient}

$$
C^{2}=\frac{\chi^{2}}{N \min \{(r-1),(c-1)\}}, \quad \text { or } \quad C=\sqrt{C^{2}}
$$

Chi-Quadrat $=16,0655$

$\mathrm{C}^{2}=0,198339506$

$\mathrm{C}=0,445353237$

$$
\begin{gathered}
\text { Chuprov's contingency coefficient } \\
T^{2}=\frac{\chi^{2}}{N \cdot \sqrt{(r-1)(c-1)}}, \quad \text { or } \quad T=\sqrt{T^{2}}
\end{gathered}
$$

$\mathrm{T} 2=0,114044497$

$\mathrm{T}=0,337704748$

The Chi-square value in test of association reached the value of 16.0655 . We can recognize a stochastic correlation between the role of innovation and help of innovative solutions. Close correlation is expressed by two coefficients: the value of Cramer's contingency coefficient is 0.445353237 , the Chuprov's coefficient of contingency reached a value of 0.337704748 . The above mentioned coefficients would show independence at 0 values. It is not fulfilled, because the values indicate correlation between the variables. Employees of the company are involved in certain stages of innovation process and some stages of the implementation process. Innovation contributes to better cooperation. Hypothesis can be confirmed, as we can see the results.

\section{Discussion}

In the 21st century, human resources have an indispensable role in the process of innovation and are a creative element in every organization, people design and produce goods, provide services, control quality, care for product marketing, allocate financial resources, and set the overall strategy and goals organizations. Human resources are the most valuable and, as a rule, the most expensive resource for a 
financial institution, which greatly contributes to its competitiveness, even though the future will probably be a human-like computer with a connection with imagination that leads to robotics.

Stimulating innovation in enterprises is an integral part of good governance and part of quality management approaches, innovations in practice. The economic, political and technological environment has changed significantly both at national and international level recently. Among the most important challenges that affect the development of the economic environment are globalization, talent management, professionalization of HR managers, knowledge management, performance management, creative approach and innovation management. All these new challenges also have implications for human resource management, which ultimately innovate outdated processes in human resource management, and therefore these challenges can also be described as innovative elements and elements in human resource management [15].

In the world of business, there is a constantly up to date question: "How better than competing"? Over the course of a decade, however, the answer to this question has changed. In the past, it was true that the one who provides the customer with a higher quality has greater chances for him her. Today, the high quality of its products and services is as high as many producers that quality as a competitive advantage has lost on its original. Recent research shows that a new factor is coming to the fore, which distinguishes successful companies from those less successful, that is, working

with people. Today, it is undisputed that the quality of human resources and their willingness to work and the good of the company is a basic sign that distinguishes successful firms from those of others as well as the upcoming era of robots.

\section{Conclusion}

It is important to recognize, that an enterprise is not a charity organization. The main objective of business is to make profit and accommodate to market conditions. Hiring the appropriate staff and motivate them to achieve common goals is an essential factor. Our objective is to explore those hidden aspects, which can be improved with administration, different types of motivation tools or simply by accepting facts. We compared the data of fluctuation from the perspectives of staff and the management. The management estimated the level of fluctuation at $5 \%$, while the questionnaire survey shows that $11 \%$ of employees would leave their workplace. Employees do not receive regular feedback about their performance. The feedback of information does not work properly. If employees understand why they carry out tasks, they will better understand and accept decisions. Praise is one of the motivation tools which are not used appropriately by the managers. Our results show, that financial incentive is still the most attractive motivational tool among the employees. The phenomenon can be understood when we come to analysis of employee's age. About $70 \%$ of employees fall into the age group of 21-30, before or after establishing a family and find finances a motivating factor. This seems to be important information for the company and use 
this motivation tool properly, because employees receive annual or monthly bonus payments.

According to Fodor, motivation can be conscious, semi-conscious or unconscious, a need or desire that will affect our will and make us act [7]. Employees face innovation at work, but understanding the innovation process is not really successful. They marked the following factors as obstacles: lack of accurate information, unclear instructions, misunderstanding of objectives. It is necessary to explore the reasons of employee fluctuation. It does not require further investment and administration can help to explore the reason why employees leave the company? The company would benefit from more frequent use of „verbal praise” as a tool of motivation. The company should invest into training, where managers can learn about verbal praise and its importance on the workplace. Lack of communication was mentioned several times. Feedback about work, when and what kind of information is given to employees is essential. Factors affecting innovation are also connected with communication. It is important to provide accurate information, clear instructions and use appropriate communication channels. Finding solution for the mentioned problem does not require extra costs. It can increase the responsibility and transparency, as well as decrease workplace stress.

\section{Acknowledgements.}

The scientific article is a partial result of the research carried out with the support of the Hungarian Academy of Sciences (1051 Budapest, Nádor utca 7) by the DOMUS HUNGARICA scholarship.

\section{References}

1. Bakacsi, GY.: Szervezeti Magatartás és Vezetés. Budapest CORVINUS Egyetem: Aula Kiadó Kft, Budapest (2004).

2. Bason, C.: Leading Public Sector Innovation. University of Bristol: The Policy Press, Bristol (2010).

3. Buzás, N., Lukovics, M.: A felelősségteljes innovációról. Közgazdasági Szemle 62(4), 438-456 (2015) .

4. Dobák, M., Antal, Z.: Vezetés és szervezés. AULA KIADÓ, Budapest (2010).

5. Dobai Korcsmáros, E.: The importance os smes in terms of development of the Nitra region. In: Fetisovová, E., Tršt’anská, A. (eds.) Aktuálne problémy podnikovej sféry 2012, pp. 59-62, EKONÓM, Bratislava (2012).

6. Dudáš, T., Kulcsár, Z., Sánta, S., Simon, M.: Tematikus gazdasági szótár. Komárno: Selye János Egyetem, Gazdaságtudományi Kar, Komárno: Selye János Egyetem, Slovensko (2012).

7. Fodor, L.: Fejezetek a motivációkutatásból. Budapest: Gondolat Kiadó, Budapest (2012)

8. Hitka M, Vetráková M, Balážová Ž, Danihelová Z.: Corporate Culture as a Tool for Competitiveness Improvement. Procedia Economics and Finance 34(2015), 27-34 (2015), DOI: 10.1016/S2212-5671(15)01597-X.

9. Karoliny, M., Poór, J.: Emberi eröforrás menedzsment kézikönyv. Budapest: Complex Kiadó Jogi és Üzleti Tartalomszolgáltató Kft., Budapest (2013). 
10. Koraus, A., Kascakova, Z., Parova, V., Veselovska, S.: 2017. Sustainable economic development through human resource management: Social intelligence of managers and performance. Journal of Security and Sustainability 6(3), 457-477 (2017), DOI: https://doi.org/10.9770/jssi.2017.6.3(11).

11. Mura, L., Sleziak, J.: Innovation and Entrepreneurship Network. In: CERS 2014 5th Central European Conference in Regional Science, International Conference Proceedings, pp. 643-651, Košice : Technical University of Košice, Košice (2015).

12. Pakucs, J. Papane, G.: Az innovációs folyamatok szervezése. Magyar Innovációs Szövetség, Budapest (2007).

13. Poór, J.: Nemzetköziesedés és globalizáció az emberi erőforrás menedzsmentben. Budapest: Complex Kiadó Jogi és Üzleti Tartalomszolgáltató Kft., Budapest (2013).

14. Poór, J. Farkas, F.: Átalakuló emberi erőforrás menedzsment a multinacionális cégek helyi leányvállalatainál Közép és Kelet-Európában. Gödöllő: Szent István Egyetemi Kiadó, Budapest (2012).

15. Sojka, L., Svátková, S.: Výzvy v riadení l’udských zdrojov v novom miléniu. Dostupné na: https://www.pulib.sk/web/kniznica/elpub/dokument/Kotulic24/subor/Sojka_Svatkova.pdf, last accessed 2017/10/26.

16. Tóth-Bordásné, M. I., Bencsik, A.: Az emberi erÖforrás mendszment. Győr: UNIVERSITAS-GYŐR Nonprofit Kft., Győr (2011).

17. Vlacseková, D., Mura, L.: Effect of motivational tools on employee satisfaction in small and medium enterprises.Oeconomia Copernicana 8(1), 111-130. DOI: 10.24136/oc.v8i1.8. 